\title{
Pengelolaan Praktik Kerja Industri Berbasis Mutu di SMK Negeri 3 Wonosari
}

\author{
Joko Suharjanto ${ }^{1}$, Muhammad Munir ${ }^{2}$ \\ ${ }^{1,2}$ Program Studi Pendidikan Teknik Elektronik aFakultas Teknik Universitas Negeri Yogyakarta \\ E-mail: .
}

\begin{abstract}
This reseach aim to improving the planning, organizing, implementing, evaluation of quality-based industry work practices at SMK Negeri 3 Wonosari. This research is a descriptive study with a survey approach and Ex Post Facto. Data collection is done through interviews, observation, documentation. The technical data analysis used is to summarize the results of interviews and documentation to be processed and concluded. The results showed that (1) the planning of the quality-based industry work practices of SMK Negeri 3 Wonosari was well implemented through team coordination, socialization, internal and external debriefing for students, DU/DI inventory, (2) the organization of quality-based industry work practices at SMK Negeri 3 Wonosari has been well implemented through the coordination of a clear Team coordinator, (3) the implementation of quality-based industrial work practices at SMK Negeri 3 Wonosari has been well implemented through student grouping student release, monitoring, student withdrawal. Students carry out apprenticeship for 3 months, (4) the evaluation of quality-based industry work practices at SMK Negeri 3 Wonosari has been carried out well through evaluation meetings involving the Prakerin team, school management, interpreters.
\end{abstract}

Keywords: industrial work practices, quality based, SMK Negeri 3 Wonosari

\begin{abstract}
ABSTRAK
Penelitian ini bertujuan untuk mengetahui perencaanaan, pengorganisasian, pelaksanaan, evaluasi praktik kerja industri berbasis mutu di SMK Negeri 3 Wonosari. Penelitian ini merupakan penelitian deskriptif dengan pendekatan Survey dan Ex Post Facto. Pengumpulan data dilakukan melalui wawancara, observasi, dokumentasi. Teknis analisis data yang digunakan adalah dengan merangkum hasil wawancara dan dokumentasi untuk diolah dan disimpulkan. Hasil penelitian menunjukkan bahwa (1) perencaanaan praktik kerja industri berbasis mutu SMK Negeri 3 Wonosari sudah dilaksanakan dengan baik melalui koordinasi tim, sosialisasi, pembekalan pihak internal dan eksternal untuk siswa, inventarisasi DU/DI (2) pengorganisasian praktik kerja industri berbasis mutu di SMK Negeri 3 Wonosari sudah dilaksanakan dengan baik melalui koordinasi koordinator Tim yang jelas, (3) pelaksanaan praktik kerja industri berbasis mutu di SMK Negeri 3 Wonosari sudah dilaksanakan dengan baik melalui pengelompokan siswa, pelepasan siswa, monitoring, penarikan siswa. Siswa melaksanakan prakerin selama 3 bulan, (4) evaluasi praktik kerja industri berbasis mutu di SMK Negeri 3 Wonosari sudah dilaksanakan dengan baik melalui rapat evaluasi yang melibatkan tim Prakerin, manajemen sekolah, pihak jurusan..
\end{abstract}

Kata kunci: praktik kerja industri, berbasis mutu, SMK Negeri 3 Wonosari

\section{PENDAHULUAN}

Pelaksanaan pembangunan pendidikan nasional di Indonesia mendapat pencerahan sejak disahkan Undang-Undang No. 20 Tahun 2003 tentang Sistem Pendidikan Nasional, melalui penjelasan visi dari pembangunan pendidikan nasional ialah terwujudnya manusia Indonesia yang produktif, cerdas, dan berakhlak mulia [1]. Serta sesuai dengan pembukaan UUD
1945 alinea 4 yang memiliki tujuan nasional Indonesia ialah untuk memajukan kesejahteraan umum dan mencerdaskan kehidupan bangsa [2]. Dalam rangka mencapai visi pembangunan pendidikan nasional serta tujuan nasional tersebut, masih ada beberapa permasalahan yang dihadapi dunia pendidikan pada umumnya, diantaranya banyak pengangguran terdidik, kurangnya dana pendidikan serta masih rendahnya kualitas lulusan. Khusus pada 
pendidikan kejuruan perlu pengelolaan yang baik, agar menghasilkan lulusan yang memiliki wawasan luas, ketrampilan, sikap profesional kerja, dan siap terjun kedunia kerja.

Dalam Peraturan Pemerintah Republik Indonesia No. 19 tahun 2003 tentang Standar Nasional Pendidikan menyiratkan bahwa tujuan pendidikan kejuruan mengandung makna bahwa SMK menyiapkan lulusan supaya menjadi tenaga kerja yang professional [3]. Media pengajaran berbasis hands-on dalam pendidikan kejuruan diperlukan untuk mengembangkan keterampilan praktik [4]. Selain melalui penggunaan media, hal tersebut dapat diperoleh dengan praktik secara langsung di tempat industri. Oleh karena itu pembelajaran yang dilaksanakan di lingkungan sekolah tidak cukup, tetapi juga dilaksanakan pembelajaran di dunia kerja, yang disebut dengan Pendidikan Sistem Ganda (PSG) atau Praktik Kerja Industri (Prakerin).

Prakerin diselenggarakan untuk membantu peserta didik terkait pemantapan hasil belajar yang diperoleh disekolah serta membekali siswa dengan pengalaman nyata sesuai dengan kompetensi keahlian yang dipilihnya [5]. Praktik Kerja Industri merupakan program kurikulum SMK yang wajib ditempuh dan sangat penting dalam rangka untuk meningkatkan ketrampilan kerja dan keprofesionalan bagi siswanya untuk menjadi manusia yang mandiri dan mampu berdaya guna dalam menghadapi dunia yang sebenarnya. Dengan demikian diperlukan pengelolaan yang baik dalam penyelenggaraan kegiatan Prakerin. Amirin menyatakan bahwa pengelolaan adalah suatu bentuk kegiatan yang meliputi perencanaan, pengorganisasian, dan pengontrolan untuk mencapai tujuan secara efektif dan efisien [6]. Pengelolaan Prakerin yang baik, akan berdampak baik pula untuk keberhasilan lembaga dalam mencapai tujuan yang lebih efektif dan efisien.

Berdasarkan hasil survey siswa SMKN 3 Wonosari melaksanakan Prakerin selama 3 bulan. Dalam pengelolaan Prakerin dilaksanakan dengan beberapa tahapan, yaitu dari perencanaan, pelaksanaan, sampai evaluasi. Namun, terdapat beberapa permasalahan yang dihadapi dalam penyelenggaraannya. Permasalahan tersebut diantaranya, saat akan melaksanakan Prakerin, siswa masih merasa ragu, merasa belum memiliki kemampuan dan kurang percaya diri. Kemudian industri yang akan digunakan oleh siswa praktik masih belum sesuai dengan kompetensi siswa. Bahkan ada yang melakukan pungutan biaya, yang membuat beban biaya yang dikeluarkan oleh siswa bertambah. Permasalahan selanjutnya yaitu kegiatan monitoring yang dilakukan oleh guru pembimbing terhadap siswa saat di industri masih kurang. Monitoring hanya dilakukan saat penyerahan dan penarikan, sehingga monitoring menjadi kurang efektif. Dalam evaluasi, pengelolaan prakerin hanya mengevaluasi tahap pelaksanaan, belum secara keseluruhan.

Berdasarkan beberapa penjelasan di atas, pentingnya suatu pengelolaan yang baik dalam kegiatan Prakerin. Perbaikan yang terus menerus dalam kegiatan Prakerin harus selalu diupayakan. Salah satu cara yang dilakukan agar terjadi peningkatan mutu Prakerin adalah dengan pengelolaan Prakerin berbasis mutu, meliputi tahap perencanaan, pengorganisasian, pelaksanaan, evaluasi. Oleh karena itu, peneliti tertarik untuk mengadakan penelitian tentang bagaimana pengelolaan Praktik Kerja Industri berbasis mutu di SMKN 3 Wonosari.

\section{METODE}

Jenis penelitian dengan menggunakan metode deskriptif ialah penelitian yang dilakukan untuk memberikan gambaran secara lebih detail tentang suatu gejala atau fenomena. Penggunaan jenis penelitian deskripsi pada penelitian ini dapat memberikan gambaran secara menyeluruh serta jelas pada situasi satu dengan situasi sosial yang lain atau dari waktu tertentu dengan waktu yang lain, atau bisa menemukan beberapa pola yang berkaitan antara aspek tertentu dengan aspek yang lain, serta bisa menemukan hipotesis serta teori. 
Subjek penelitian ini adalah orang-orang yang terlibat langsung dalam kegiatan pengelolaan Prakerin berbasis mutu di SMKN 3 Wonosari, yaitu Kepala Sekolah, Wakil Kepala Sekolah bidang Humas, Ketua Prakerin, Sekretaris prakerin, guru pembimbing, siswa dan pembimbing lapangan. Prosedur penelitian ini ialah melakukan wawancara terhadap responden/subjek penelitian, melakukan observasi, dan mengumpulkan data dokumentasi terkait dengan kegiatan pengelolaan Prakerin. Data yang diperoleh dalam penelitian ini menggunakan instrumen/pedoman wawancara, observasi, dokumentasi.

Pengumpulan data dalam penelitian ini menggunakan teknik wawancara kepada subjek penelitian, teknik observasi dan teknik dokumentasi. Wawancara adalah suatu metode yang digunakan untuk mendapatkan jawaban dari responden dengan cara tanya jawab [7]. Dalam wawancara ini yang dilakukan peneliti yaitu dengan menggali informasi, mencari keterangan, atau penjelasan dari informan terkait dengan pengelolaan Praktik Kerja Industri. Wawancara dilakukan dengan menggunakan pedoman wawancara yang telah disiapkan oleh peneliti. Kemudian hasil dari wawancara akan digali lebih rinci lagi, dipelajari, dan disimpulkan.

Observasi yaitu pengamatan yang dilakukan secara sengaja, sistematis, mengenai fenomena sosial dengan gejala-gejala psikis yang selanjutnya dilakukan pencatatan secara sistematik [7]. Teknik ini dilakukan untuk mengetahui pelaksanaaan Prakerin Berbasis Mutu di SMKN 3 Wonosari. Dokumentasi merupakan perlengkapan dari penggunaan penelitian kualitatif [8]. Teknik pengumpulan data dengan dokumentasi yaitu dengan mengumpulkan dokumen-dokumen terkait dengan agenda Prakerin. Dokumentasi dibutuhkan dalam penelitian ini karena data yang diperoleh bisa digunakan untuk melakukan triangulasi data penelitian dan untuk melengkapi/pendukung data yang berkaitan tentang pengelolaan Prakerin berbasis mutu di SMKN 3 Wonosari.

\section{HASIL DAN PEMBAHASAN}

\section{Perencanaan}

1. Penyusunan agenda kegiatan

2. Pembentukan dan koordinasi tim

3. Pembuatan peta DU/DI

4. Sosialisasi kegiatan prakerin

5. Pembekalan siswa (sekolah dan industri)

Pengorganisasian

1. Pembentukan tim

2. Penentuan guru pembimbing

3. Pengorganisasian fasilitas

Pelaksanaan

1. Pengelompokkan siswa

2. Pengajuan permohonan ke industri

3. Penyerahan siswa prakerin

4. Kegiatan di industri

5. Penilaian pihak industri dan pembimbing

6. Monitoring oleh pembimbing

7. Penarikan

8. Pengumpulan dokumen pelaksanaan prakerin oleh siswa

Evaluasi

1. Rapat Tim tentang perkembangan siswa dan kelayakan industri

2. Evaluasi pihak jurusan tentang kesesuaian kompetensi antara sekolah dan industri

Gambar 1. Tahapan kegiatan pelaksanaan prakerin di SMK Negeri 3 Wonosari

Gambar 1 menunjukkan tahapan kegiatan pelaksanaan prakerin di SMK Negeri 3 Wonosari secara umum. Gambar tersebut disarikan dari hasil wawancara dengan pihak SMKN 3 Wonosari dan kajian yang terkait. Secara umum kegiatan prakerin terdiri atas, perencanaan, pengorganisasian, pelaksanaan dan evaluasi. Setiap tahapan tersebut dilakukan untuk memastikan mutu pelaksanaan prakerin.

Sebelum pelaksanaan Prakerin dimulai pastinya terdapat perencanaan sebelumnya agar pelaksanaan Prakerin berjalan lebih efektif dan 
efisien. Perencanaan Prakerin di SMK Negeri 3 Wonosari dimulai setiap awal tahun ajaran baru, dengan meliputi penyusunan agenda kegiatan. Hasil penelitian tersebut didukung adanya wawancara dengan Ketua Prakerin: "Perencanaan prakerin biasanya dilaksanakan pada tahun ajaran baru. Meliputi agenda kegiatan, pemetaan industri sesuai kompetensi masing-masing."

Selain itu, kegiatan awal dalam perencanaan Prakerin yaitu pembentukan dan koordinasi tim. Lalu berkoordinasi dengan manajemen sekolah terutama dibagian kurikulum terkait dengan jadwal pelaksanaan sesuai dengan agenda yang ada di kurikulum. Hasil penelitian tersebut didukung adanya wawancara dengan Waka Humas: "Kita mulai dari pembentukan Tim Prakerin, lalu koordinasi dengan manajemen, dengan kurikulum terkait dengan waktu pelaksanaan yang tepat sesuai dengan agenda yang ada di kurikulum. Kemudian juga terkait dengan pembiayaan, kita membuat atau memasukan anggaran Prakerin pada RKAS (Rencana Kerja Anggaran Sekolah) yang awal kita persiapkan."

Kegiatan selanjutnya adalah pembuatan peta DU/DI. Hasil penelitian tersebut didukung adanya wawancara dengan Waka Humas: "Untuk peta DU/DI kita melakukan inventarisasi sebelum anak-anak mendapatkan tempat praktik. Kita melakukan inventarisasi terhadap beberapa industri tempat PKL. Jadi memang disitu kita melakukan pemetaan. Ada industri yang memang tidak memenuhi persyaratan atau mungkin ada beberapa kompetensi yang harusnya didapat disana, kemudian sulit dicapain disana. Mungkin pelaksanaan yang akan datang industri demikian tidak akan digunakan lagi." Hal di atas juga didukung dengan syarat/kriteria DU/DI yang dipergunakan untuk tempat Prakerin yaitu sesuai dengan kompetensi siswa.

Dalam sosialisasi disampaikan mengenai tentang kegiatan Prakerin yang akan dilakukan, prosedur mencari tempat Prakerin serta bagaimana proses pengajuannya, apa yang harus dipersiapkan, dan lain-lain. Hasil penelitian tersebut didukung adanya wawancara dengan Ketua Prakerin: "Semacam prosedur untuk pengajuan, misal nanti ada industri baru harus bagaimana. Karena industri baru harus ada cheklist, terus kita nilai dulu seberapa cocokah industri dengan kompetensinya."

Pembekalan dilaksanakan saat menjelang Prakerin dimulai, yaitu maksimal satu minggu sebelumnya. Hasil penelitian tersebut didukung adanya wawancara dengan Ketua Prakerin: "Pembekalan biasanya diselenggarakan paling lambat 1 bulan sebelum pelaksanaan sampai mendekati 1 minggu sebelum pemberangkatan PKL ke industri. Karena kadang pembekalan itu kalau sudah dilakukan diawal itu kemungkinan bisa, tapi untuk non teknisnya. Cuma untuk yang teknis karena kita harus menyesuaikan dengan industri masing-masing. Jadi sebisa mungkin kalau anak-anak sudah mendapatkan industri semua."

Dalam pembekalan disampaikan dari pihak sekolah dan industri, dengan materi tentang penguatan mental, tata tertib, gambaran kepada siswa mengenai pelaksanaan praktik di industri. Hasil penelitian tersebut didukung adanya wawancara dengan Ketua Prakerin: "Teknis dan non teknis. Untuk yang non teknis itu ada tata cara, tata tertib, kesekretariatan penuliasan laporan. Sementara untuk yang teknisnya ada sesuai dengan industrinya masing-masing. Misalnya dibidang service elektronika, nanti ada pembekalan tentang service elektronika. Bagaimana cara membuka perangkat elektronika. Atau mungkin yang di boga dikenalkan dengan peralatan-peralatan dan bagaimana cara kerja didapur. Mungkin juga yang dibagian pendingin mungkin langsung dikenalkan dengan alat-alat yang ada disekolah."

Perencanaan Prakerin dilaksanakan pada tahun ajaran baru yang dilaksanakan secara terus menerus. Kegiatan awal yang dilakukan dalam perencanaan adalah koordinasi tim, sosialisasi, pembekalan siswa, pemetaan DU/DI.Dalam Prakerin, DU/DI berpengaruh besar dalam pelaksanaannya. Oleh karena itu, dalam tahap perencanaan dilakukan pemetaan DU/DI dengan 
kriteria harus sesuai dengan kompetensi siswa. Dalam perencanaan terdapat kegiatan sosialisasi dan pembekalan. Sosialisasi bertujuan untuk menyampaikan mengenai berbagai hal kegiatan Prakerin yang akan dilaksanakan. Pembekalan dilakukan untuk mempersiapkan diri siswa saat akan melaksanakan Prakerin. Dalam pembekalan tersebut, siswa diberikan materi tentang tata tertib, tata cara pelaksanaan praktik di industri, penguatan mentan dan lain sebagainya. Pembekalan disampaikan pihak sekolah dan industri.

Berdasarkan dengan hasil penelitian dapat dikatakan bahwa perencanaan Prakerin di SMK Negeri 3 Wonosari sudah baik, mengacu pada perencanaan berbasis mutu. Kriteria yang menunjukkan bahwa perencanaan Prakerin sudah disusun dengan baik, yaitu koordinasi tim, sosialisasi yang intensif kepada siswa dan orang tua, pembekalan yang melibatkan pihak internal sekolah, dan pihak eksternal dari industri untuk bekal siswa sebelum prakerin.

Pengorganisasian dalam manajemen pendidikan pada saat Prakerin Berbasis Mutu dimulai dengan mengorganisasian sumbersumber dan fasilitas yang dapat digunakan. Sumber daya yang ada dikoordinasikan dalam pelaksanaan Prakerin. Pengorganisasian Prakerin di SMK Negeri 3 Wonosari dimulai dengan berkoordisasi tentang kegiatan Prakerin lalu pembentukan tim. Hasil penelitian tersebut didukung adanya wawancara dengan Waka Humas: "Koordinasi pelaksanaan PSG ini juga tidak lepas dari praktik kerja lapangan. PSG yang dimaksud disini penerapannya lebih banyak dalam bentuk praktik kerja lapangan. Kemudian untuk koordinasi program ini, kita libatkan kurikulum, kesiswaan, sarana prasarana, lalu tim terkait yaitu tim praktik kerja lapangan."

Setelah tim terbentuk kemudian menentukan guru pembimbing untuk siswa Prakerin. Guru pembimbing berasal atau berlatar belakang guru mata pelajaran kejuruan. Hasil penelitian tersebut didukung adanya wawancara dengan Sekretaris Prakerin: "Tentunya yang menjadi guru pembimbing ditempat kita biasanya guru produktif/kejuruan. Tapi tidak menutup kemungkinan guru normatif adaptif juga bisa. Karena guru produktif yang lebih menjurus dan nanti saat diindutri yang diajarkan juga bidang kejuruannya."

Pengorganisasian juga dilakukan terhadap fasilitas yang digunakan dalam Prakerin serta pembiayaan Prakerin. Siswa menggunakan biaya sendiri. Sekolah hanya membiayai administrasi sekolah dan tim. Hasil penelitian tersebut didukung adanya wawancara dengan Waka Humas: "Terkait fasilitas, kita mengupayakan pada saat perencanaan RKAS itu. Kebutuhan-kebutuhan terkait prakerin itu tercukupi dari sana. Jadi kebutuhan-kebutuhan tim, tapi bukan kebutuhan untuk siswa secara langsung seperti biaya makan, kost, transportasi memang jadi tanggungjawab orang tua siswa. Tapi terkait dengan tim, seperti transportasi tim, sovenir dari kita untuk industri, pembekalan sebelum berangkat PKL itu dibiayai oleh RKAS."

Pengorganisasian Prakerin dilakukan dengan mengorganisasian sumber-sumber dan fasilitas yang dapat digunakan. Sumber daya yang ada dikoordinasikan untuk pelaksanaan Prakerin. Koordinasi sumber daya dilakukan oleh bagian Humas, Kurikulum, dengan Ketua jurusan. Adapun koordinasi dimulai sejak SK Panitia diterbitkan. Tim Prakerin juga membentuk guru pembimbing siswa Prakerin. Pengorganisasian juga dilakukan terhadap fasilitas yang digunakan dalam Prakerin serta pembiayaan Prakerin. Namun sekolah hanya membiayai administrasi sekolah dan kebutuhan tim pelaksana. Terkait fasilitas, sekolah menyediakan fasilitas yang dibutuhkan siswa guna memperlancarkan kegiatan Prakerin seperti beberapa daftar industri yang bisa digunakan, pembuatan surat izin, contoh-contoh laporan untuk referensi. Dari industri ada yang memberikan beberapa fasilitas yang mungkin berbeda dari industri yang satu dengan industri yang lainnya.

Berdasarkan dari hasil penelitian dapat dikatakan pengorganisasian Prakerin di SMK Negeri 3 Wonosari sudah dilaksanakan dengan 
baik. Ada beberapa kriteria yang menunjukkan bahwa pengorganisasian Prakerin sudah disusun dengan mutu baik, yaitu adanya penunjukan sumber daya manusia yang bertanggung jawab dan berkompeten, ada manajemen sarana dan prasarana pendukung yang tersedia dalam pelaksanaan, dan ada alokasi anggaran.

Pelaksanaan Prakerin Berbasis Mutu dimulai pengelompokan siswa dalam beberapa jurusan. Hal ini dilakukan untuk keperluan permohonan kepada pihak DU/DI sesuai dengan kuota yang tersedia. Dalam pemilihan DU/DI, siswa diberikan kesempatan untuk bebas memilih namun diarahkan oleh tim/sekolah. Hasil penelitian tersebut didukung adanya wawancara dengan Ketua Prakerin: "Kalau di SMK 3 siswa dibebaskan memilih dan kita yang dari sekolah menawarkan beberapa industri yang sudah kerja sama. Tetapi siswa juga tetap bebas memilih. Karena dulu waktu kita tentukan ternyata banyak juga kendala kendala dilapangan setelah pelaksanaanya. Siswa nanyak yang tidak betah. Jadi meraka bebas memilh tapi tetap ada analisa dari kita. Kalau memang anaknya mampu diindustri itu, berarti bisa lanjut. Tapi kalau kira-kira tidak mampu disitu, sebaiknya pindah ke industri yang lain. Bebas memilih tapi ada batasan-batasan aturannya."

Kegiatan selanjutnya yaitu siswa mengajukan surat permohonan untuk industri yang dituju. Surat dibuat oleh tim setelah siswa mendaftarkan secara berkelompok ke tim panitia. Hasil penelitian tersebut didukung adanya wawancara dengan Ketua Prakerin: "Prosedurnya anak-anak menulis dibuku pengajuan tempat $P K L$. Nanti ditulis ada berapa anak dalam 1 kelompok lalu siapa saja, industrinya mana. Nanti kalau memang di industri itu belum ada yang memilih, kita buatkan surat permohonan yang mestinya industri itu telah sesuai dengan kemampuan siswa. Kalau sudah ada yang memilih berarti harus cari yang lainnya. Jadi siswa mengajukan ke tim dulu untuk kita buatkan surat permohonannya."
Kegiatan selanjutnya yaitu penyerahan siswa Prakerin. Kegiatan penyerahan siswa Prakerin dilakukan oleh guru pembimbing langsung ke industri. Hasil penelitian tersebut didukung adanya wawancara dengan Ketua Prakerin: "Prosedurnya pembimbing dari sekolah menyerahkan ke industri. Biasanya nanti langsung diantar dihari pertama masuk ke industri walaupun mungkin tidak sekaligus dalam 1 hari. Mungkin pagi langsung diserahkan, tapi karena kami terkendala dengan guru pembimbing. Jadi 1 guru pembimbing bisa sampai membimbing 4 kelompok/industri. Jadi kalau menyerahkan dalam 1 hari biasanya ada yang pagi, siang, sore atau dihari berikutnya. Tapi diusahakan untuk tetap diantar ke industri."

Kegiatan selanjutnya yaitu kegiatan di industri. Waktu praktik di industri selama 3 bulan dan penempatannya diatur oleh industri. Hasil penelitian tersebut didukung adanya wawancara dengan Ketua Prakerin: "Siswa langsung praktik ke industri yang dipilih. Industri yang telah cocok dan sesuai dengan kompetensi siswa, industri yang sudah dikenal siswa itu. Dengan jangka waktu 3 bulan. Untuk penempatannya di indutri menyesuaikan dengan tugas yang ada di indutri. Nanti pembimbing industri yang mengatur penempatan kerjannya."

Selama prakerin berlangsung, siswa dinilai oleh pihak industri dan guru pembimbing juga menilai diakhir Prakerin. Hasil penelitian tersebut didukung adanya wawancara dengan Ketua Prakerin: "Penilaiannya ada dari industri yang berupa sertifikat. Lalu ada juga dari sekolah yaitu dari pembimbing sekolah. Kalau dari industri kita sudah buatkan formatnya, yaitu ada 1 aspek yang dinilai, baik yang teknis maupun non teknis. Begitu juga yang dari guru pembimbing sekolah juga ada aspek yang dinilai, yaitu ada laporan dan praktik."

Selama Prakerin dilakukan monitoring oleh guru pembimbing. Monitoring dilakukan untuk mengetahui kinerja siswa selama praktik, mengetahui sama atau tidaknya kompetensi keahlian siswa dengan pekerjaan yang dilakukan di tempat praktik/industri. Hasil penelitian 
tersebut didukung adanya wawancara dengan Guru Pembimbing: "Yang pertama untuk yang dimonitoring dari ranah administrasi itu kehadiran. Bagaimana anak itu hadir terus atau tidak. Kemudian kinerja anak. Apakah anak itu melakukan kegiatan benar atau hanya hadir tapi cuma duduk-duduk saja atau tidak melakukan aktivitas pekerjaan disana. Kemudian dari kinerja itu ada banyak unsur. Jadi bagaimana kerjanya ditempat praktik. Kemudian monitoring sikap, misal bagaimana sikap dan perilaku anak-anak di industri selama melakukan prakerin. Apakah ada perkembangan membaik atau malah terlihat penurunan dari sikap-sikap yang biasanya, dari baik menjadi tidak baik. Itu juga kita tanyakan ke pihak industri, sekaligus kita mengumpulkan data dan fakta untuk anak setelah anak melaksanakan prakerin nanti. Setidaknya ada kemajuan."

Kemudian selanjutnya adalah penarikan. Penarikan dilakukan sesuai waktu yang telah ditentukan atau sesuai kesepakatan. Hasil penelitian tersebut didukung adanya wawancara dengan Ketua Prakerin: "Penarikan dilakukan 1 minggu sebelum kegiatan PKL selesai, itu sudah boleh dilakukan. Tapi walaupun sudah ditarik diawal minggu, siswa harus bertahan sampai akhir PKL. Misal PKL berakhir dihari sabtu, lalu bisanya ditarik hari senin sebelumnya, anak-anak harus tetap berada diindustri sampai hari sabtu. Jadi pas begitu ditarik langsung selesai, tapi sesuai dengan kontrak permohonannya." Kemudian siswa kembali ke sekolah dengan membawa sertifikat yang berisi nilai pelaksanaan kegiatan Prakerin siswa serta buku jurnal dan buku pembimbing yang telah diisi oleh pembimbing industri serta mengumpulkan laporan.

Pelaksanaan Prakerin di SMK Negeri 3 Wonosari merupakan program kurikulum sekolah kejuruan wajib tempuh yang dilakukan di industri kurang lebih selama 3 bulan. Berdasarkan hasil wawancara dan analisis dokumen, kegiatan-kegiatan dalam pelaksanaan Prakerin yaitu pencarian tempat praktik, pengajuan tempat praktik, penyerahan siswa ke industri, pelaksanaan dan penempatan siswa di industri, monitoring, penarikan dan penilaian. Dalam pencarian tempat praktik, siswa bebas memilih namun diarahkan oleh tim Prakerin. Surat pengajuan dibuatkan oleh tim setelah siswa memilih tempat prakerin yang akan dituju. Penyerahan, monitoring, penarikan dilakukan oleh guru pembimbing ke industri langsung. Selama pelaksanaan praktik di industri, penempatan siswa praktik diatur dan dibimbing oleh pembimbing industri. dalam penilaian semua diserahkan oleh pembimbing industri. guru pembimbing juga melakukan penilaian diakhir kegiatan Prakerin.

Berdasarkan dari hasil penelitian dapat dikatakan bahwa pelaksanaan Prakerin di SMK Negeri 3 Wonosari sudah dilakukan dengan baik, mengindikasikan berbasis mutu. Kriteria yang menunjukkan bahwa pelaksanaan Prakerin Berbasis Mutu sudah disusun dengan baik, yaitu ada langkah-langkah yang jelas dan dilaksanakan sesuai dengan perencanaan yang disusun sebelumnya, serta monitoring oleh guru pembimbing terhadap pelaksanaan yang intensif, pembimbing merupakan guru yang kompeten di bidangnya, komunikasi yang efektif dengan pihak DU/DI, dan mengedepankan kualitas industri.

Evaluasi dilakukan dengan rapat oleh tim Prakerin, guru pembimbing dan manajemen sekolah membahas tentang perkembangan anak, kelayakan industri yang dipakai untuk praktik. Hasil penelitian tersebut didukung adanya wawancara dengan Ketua Prakerin: "Evaluasi dilakukan lewat tim. Jadi tim mengadakan rapat evaluasi beserta pembimbing. Bagaimana industri masih layak dipakai atau tidak. Karena kadang di cheklist kesesuaian sudah bagus, tapi ternyata dilapangan kadang berbeda, jadi tetap kita lakukan evaluasi diakhir, walaupun ada juga tidak sesuainya diketahui diawal, itu langsung kita tarik. Pembimbing sekolah langsung memberi kabar ke tim PKL, lalu kita buatkan surat penarikan. Karena jika dibiarkan terus nanti takutnya anak-anak tidak mendapatkan hasil yang maksimal."

Evaluasi juga dilakukan pihak jurusan. Evaluasi dilakukan untuk membahas tentang 
pengkajian penempatan siswa yang akan praktik dengan kompetensi siswa yang praktik di sebuah industri. Apakah sesuai yang diharapkan industri atau tidak. Hasil penelitian tersebut didukung adanya wawancara dengan Guru Pembimbing: "Dari jurusan ada. Di SMK 3 itu ada 2 kelompok program keahlian ada elektronika dan pariwisata. Disitu penempatan siswa didasarkan pada catatan-catatan tahun kemarin, dalam hal ini evaluasi tahun kemarin. Jika didapat suatu tempat prakerin ada kendala ditahun kemarin, misalkan anaknya kurang kompeten atau tidak sesuai dengan apa yang diharapkan industri, maka tahun ini pas penempatan di industri tersebut biasanya diambilkan anak yang sesuai dengan yang diminta oleh pihak DU/DI. Jadi ada evaluasi dari jurusan. Karna yang lebih tahu tentang kompetensi anak itu dari pihak jurusan. Pihak jurusan hanya menyortir tempat industri dan juga memberi catatan-catatan ataupun evaluasi, tetapi diranah industrinya. Apakah masih layak untuk dijadikan tempat prakerin lagi atau tidak. Kalau sudah tidak berarti tahun ini harus dioffkan atau tidak digunakan lagi untuk prakerin. Jadi sekolah juga melakukan evaluasi ranahnya pengkajian tempat DU/DI. Karena memang tadinya ada industri yang bonafit, tiba-tiba rugi, akhirnya tidak bagus untuk produksi atau tempat untuk prakerin. Jadi tiap tahun ada evaluasi dari sekolah berhubungan tempat prakerin, sementara jurusan ada evaluasi untuk penempatan siswa ketempat prakerin."

Evaluasi Prakerin di SMK Negeri 3 Wonosari dilakukan melalui rapat evaluasi. Kegiatan evaluasi ini melibatkan beberapa pihak, antara lain tim Prakerin, Humas, manajemen sekolah, Ketua jurusan, guru pembimbing. Dalam pelaksanaan evaluasi ini, semua pihak yang terlibat di lapangan harus menyampaikan hasil temuan-temuan, mengumpulkan dan melihat data-data yang ada selama pelaksanaan Prakerin. Data tersebut terkait tempat pelaksanaan siswa praktik, hasil monitoring, penilaian industri seperti kuisioner dari industri dan laporan siswa. Kemudian dianalisis untuk mengetahui tingkat pencapaian sasaran Prakerin. Dari pihak jurusan juga melakukan evaluasi. Evaluasi dari jurusan dilakukan untuk membahas tentang pengkajian penempatan siswa yang akan praktik dengan kompetensi siswa yang praktik di sebuah industri. Apakah sesuai yang diharapkan industri atau tidak.

Berdasarkan dari hasil penelitian, dapat dikatakan bahwa evaluasi Prakerin di SMK Negeri 3 Wonosari sudah dilaksanakan dengan mengacu pada kriteria mutu baik, yaitu ada metode evaluasi yang jelas dan telah ditetapkan sebelumnya, ada penentuan pihak yang melakukan penilaian, dan ada koordinasi antara guru dengan pihak yang melakukan penilaian secara langsung terhadap siswa dalam pelaksanaan praktik kerja.

Pengelolaan Prakerin berbasis mutu di SMKN 3 Wonosari terdiri atas empat kegiatan utama, yaitu perencanaan, pengorganisasian, pelaksanaan, dan evaluasi. Tahapan kegiatan tersebut tidak jauh berbeda dengan tahapan kegiatan prakerin di SMKN 4 Malang [9]. Hasil penelitian tersebut menunjukkan tahapan kegiatan prakerin berbasis mutu di SMKN 3 Wonosari. Selain hal tersebut, beberapa hal yang diperoleh selama proses pengumpulan data akan tetapi belum diperoleh data lebih lanjut di diantaranya adalah: (1) model pembelajaran di tempat prakerin; (2) faktor-faktor yang mempengaruhi kesuksesan prakerin; dan (3) penggunaan teknologi dalam pelaksanaan prakerin untuk mendukung era Industri 4.0. Evolusi Teknologi Informasi dan Komunikasi (TIK) yang cepat mengubah wajah pendidikan dan pelatihan kejuruan, terutama ketika TIK dikombinasikan dengan fondasi pedagogis yang memadai [10]. Penggunaan teknologi dapat diimplementasikan dalam penerapan sistem informasi untuk tahapan kegiatan prakerin [11].

\section{SIMPULAN}

Berdasarkan hasil penelitian diatas dapat diketahui bahwa dalam pengelolaan Prakerin berbasis mutu di SMKN 3 Wonosari, terdapat kegiatan perencanaan, pengorganisasian, 
pelaksanaan, dan evaluasi Prakerin. Perencanaan Praktik Kerja Industri Berbasis Mutu di SMK Negeri 3 Wonosari sudah dilaksanakan dengan baik, dilakukan melalui koordinasi tim, sosialisasi, pembekalan untuk siswa, inventarisasi DU/DI. Pengorganisasian Prakerin Berbasis Mutu berbasis mutu di SMK Negeri 3 Wonosari sudah dilaksanakan dengan mengacu pada mutu baik, dilakukan dengan penunjukan sumber daya manusia yang kompeten dan bertanggungjawab, ada manajemen sarana dan prasarana yang tersedia dalam pelaksanaan, dan ada alokasi anggaran. Pelaksanaan Prakerin berbasis mutu di SMK Negeri 3 Wonosari sudah dilaksanakan dengan baik. Kegiatan-kegiatan dalam pelaksanan Prakerin yaitu pengelompokkan siswa sesuai jurusan untuk keperluan permohonan kepada pihak DU/DI, penyerahan prakerin, kegiatan dan penempatan siswa di industri, monitoring, penilaian, penarikan. Evaluasi Prakerin Berbasis Mutu di SMK Negeri 3 Wonosari sudah dilaksanakan dengan mutu baik melalui rapat evaluasi yang melibatkan tim Prakerin dan manajemen sekolah.

Sekolah dapat menggunakan manajemen berstandar ISO, sehingga dokumen perencanaan Prakerin Berbasis Mutu terkendali secara terarah dan maksimal. Manajemen sekolah perlu menambah guru pembimbing yang memiliki kualifikasi akademik yang sesuai dan melakukan pelatihan on the job traning di industri untuk pembimbing, menambah sarana dan prasarana pendidikan yang dibutuhkan dalam pelaksanaan Prakerin. Guru SMKN 3 Wonosari diharapkan senantiasa bersedia memajukan sekolah melalui pengembangan Prakerin Berbasis Mutu. Penelitian selanjutnya perlu melakukan fokus penelitian mengenai model pembelajaran di tempat prakerin, faktor-faktor yang mempengaruhi kesuksesan prakerin dan penggunaan teknologi dalam pelaksanaan prakerin untuk mendukung era Industri 4.0.

\section{DAFTAR PUSTAKA}

[1] S. N. RI, "Undang-undang Republik Indonesia Nomor 20 Tahun 2003 tentang Sistem Pendidikan Nasional," 2003.

[2] S. J. D. RI, "Undang-undang Dasar Negara Republik Indonesia Tahun 1945 (Risalah Rapat Paripurna ke-5 Sidang Tahunan MPR Tahun 2002 sebagai Naskah Perbantuan dan Kompilasi Tanpa Ada Opini)," Dewan Perwakilan Rakyat Republik Indonesia, 2002. [Online]. Available: http://www.dpr.go.id/jdih/uu1945.

[3] S. N. RI, Peraturan Pemerintah Republik Indonesia Nomor 19 Tahun 2003 tentang Standar Nasional Pendidikan. Indonesia, 2005.

[4] P. Utami, G. P. Cikarge, M. E. Ismail, and S. Hashim, "Teaching Aids in Digital Electronics Practice through Integrating 21st Century Learning Skills using a conceptual approach," in Journal of Physics: Conf. Series, 2018, pp. 1-9.

[5] N. Susana, "Pengelolaan Praktik Kerja Industri," Manajer Pendidik., vol. 10, no. 6, pp. 579-587, 2016.

[6] T. M. Amirin, Manajemen Pendidikan. Yogyakarta: UNY Press, 2010.

[7] S. Arikunto, Prosedur Penelitian Suatu Pendekatan Praktik. Jakarta: PT. Rineka Cipta.

[8] Sugiyono, Metode Penelitian Pendidikan (Pendekatan Kuantitatif, Kualitatif, dan R\&D). Bandung: Alfabeta, 2014.

[9] A. N. Faizal, Burhanuddin, and Sultoni, "Manajemen praktik kerja industri," $J$. Adminitrasi dan Manaj. Pendidik., vol. 1, no. 2, pp. 139-149, 2018.

[10] S. Hashim, M. H. A. Rahman, D. Nincarean, N. F. Jumaat, and P. Utami, "Knowledge Construction Process in Open Learning System among Technical and Vocational Education and Training (TVET) Practitioners," J. Tech. Educ. Train., vol. 11, no. 1, pp. 73-80, 2019.

[11]S. T. Safitri and D. Supriyadi, "Rancang Bangun Sistem Informasi Praktek Kerja Lapangan Berbasis Web dengan Metode Waterfall," $J$. Infotel, vol. 7, no. 1, pp. 69-74, 2015. 